\title{
Congenital Septal Defect
}

National Cancer Institute

\section{Source}

National Cancer Institute. Congenital Septal Defect. NCI Thesaurus. Code C84482.

A congenital disorder characterized by the presence of an abnormal communication between the atria or the ventricles of the heart due to defects in the cardiac septum. 